\title{
Architecture and Spaces of Power in the Knights of St. John of Jerusalem (1530-1798) \\ Valentina Burgassi
}

Polytechnic of Turin, Turin, Italy, valentina.burgassi@gmail.com

\begin{abstract}
In the seven Centuries after its foundation, the Order of the Knights Hospitaller of St. John, said at the beginning of Jerusalem, of Rhodes and finally of Malta, reached a major economic power and a strong hierarchical structure based on the articulation of national sections. Maltese fortifications erected between 1530 and 1798 are in some respects unique; they nevertheless are a representative example of contemporary European military architecture at its best. What is very interesting is the diversity of social and professional categories of military engineers, already committed by the Pope or by the big dynastic families of the time, called to work for the Hospitaller Order. Military architecture is also reflected in bastions, curtain walls and ravelins and by 1550 military engineering in Italy, as Count Valperga, seems to have become established as a specialist practice, the first branch of architecture to achieve recognition as an independent profession.
\end{abstract}

Keywords: Knights of Saint John, military engineers, Malta, fortifications.

\section{The Knights Hospitaller}

The geographical extent of the Order property gave on one side the ability to change and to constantly improve the property, consisting of Commanderies - essential as a tool for the economic management of the heritage and for the new territories political control - and hospitals, and on the other side to make Malta a well fortified city.

During the sixteenth and seventeenth centuries, military engineers, belonging to the geographical area, now said Europe, have developed a coherent structure of fortifications. Malta, the island of the Knights of St. John, was an exceptionally well-fortified city and, because of the concentration of fortifications in a confined space and their survival over the centuries, it is a special occasion to examine in detail the planning and construction of a major defense project. But what is interesting are the attitudes of the Knights of the Order of Saint John in respect to the engineers who worked for them and the state of the different social and professional categories of used engineers. Although the fortifications in Malta between 1530 and 1798 are somehow unique, they represent an example of contemporary European military architecture at its best.

In the seven centuries after its founding, the Order of the Knights Hospitaller of St. John (early said of Jerusalem, of Rhodes and finally of Malta) reached a major economic power and a strong hierarchical administrative structure based on the organization in sections, or national languages, said «langues»: Provence, Auvergne, France, Italy, Aragon, Castile, England, Germany. Among them, the Italian language, even if it was not the oldest, was one of the most developed and included seven Grand Priories (Rome, Lombardy, Venice, Pisa, Capua, Barletta and Messina). 
The Knights stayed in Malta for 268 years, transforming what they called «merely a rock of soft sandstone» (Hoppen, 1999) into a flourishing island with mighty defences and a capital city (Valletta). The official name given by the Order of Saint John was «Humilissima Civitas».

\subsection{The structure of the Order}

The structure of the Order of Malta provided that a number of Hospitals and Priories constitues a Bailiwick, which was placed under the jurisdiction of a bailiff, while the more numerous or large groups formed a Priorate or Grand Priorate. Around half of the eighteenth century, the Order of Malta in Europe increased to a maximum of 22 Priorates and this allowed it to have Perceptorships from England to Sicily, from France to Austria.

The detailed description of the state of ecclesiastical heritage, with systematic recognition of their borders, recorded in the Inspection Acts, taking the value of Notary Deeds, becomes in the thirteenth century, the «Cabreo». The term «Cabreo», usually in Italian, also extends to the scale of the cadastral map, later accompanying the descriptive Cabreo, contrary to what happens in other languages such as French and English in which the recognition of descriptive keeps a proper name (estate-survey), separate from the cartographic design recovery, for which we used the terms estate plan-map.

The Cabreo is a tool in the economic and legal framework, which fully reflects the complex social stratification defined not only by the land property, but also by the common rights of use, related to the ecclesiastical sphere. It was in the eighteenth-nineteenth century, according to the legacy of the sixteenth, that starts developing a new culture of manuals, increasingly attentive to the map measurement and to the instrumentation that allows a more accurate territory representation. This culture has its climax in the France of Louis XV and Louis XVI with the Science of Surveyor of Dupain Montesson (1744) and the Treaty of Land Surveying of Ozanam (1758): a new profession, the cartographic surveyor, arises and grows with the specification of its functions and its technical knowledge to answer the question of a client interested in the use of the Cabrei cartography.

With the end of the Seventeenth century and the first half of the Eighteenth, the great agronomical transformations have encouraged the authorities to take, as an official figurative documentation, the Cabreo, that allowed a complete knowledge of the territory. Then, from the mid-eighteenth century, they stimulated the Central Government Authority to extend the area of known throughout the State territory, by writing the Figurative Cadastres. From the preliminary operations up to the territory government, the measurement of the physical space and the real estate estimation are stimulated by the State summit, in periods of strong power centralization, but also controlled by a specific plan of the technicians. "The war has its travellers such as science and as the fine arts». This statement, contained in an essay on the Napoleonic military recognitions, is particularly true since the time where the trench warfare and the siege practice were almost entirely supplanted by the movement warfare, with the shift operations associated houses.

\section{A new fortification style in Europe}

Already in 1691 the France of Vauban was in a position to begin to allocate a portion of its military engineers to the exclusive activity of the cartographic survey: the image of the building becomes the territorial order and the conceptual realm of nature. These changes in the European courts of the modern era conferred to occupational castes, increasingly institutional. The best engineers built Malta's fortifications and many men with great experience have found their way in Malta. Therefore, it is possible to study the relationship between the Order of Saint John and the military engineers in a place that, far from being static, has not been subject to important political, social, financial or religious changes, between 1530 and 1798. The second quarter of the sixteenth century saw the transformation of fortresses in Europe: the high walls in the towers of the Middle Ages offered 
no defence against the artillery powder. A new fortification style emerged in Europe on the basis of the bastions: the system of bastion fortifications was quickly adopted throughout Europe and colonial empires: the bastioned fortresses remain an essential element of military strategy to the end of the eighteenth century.

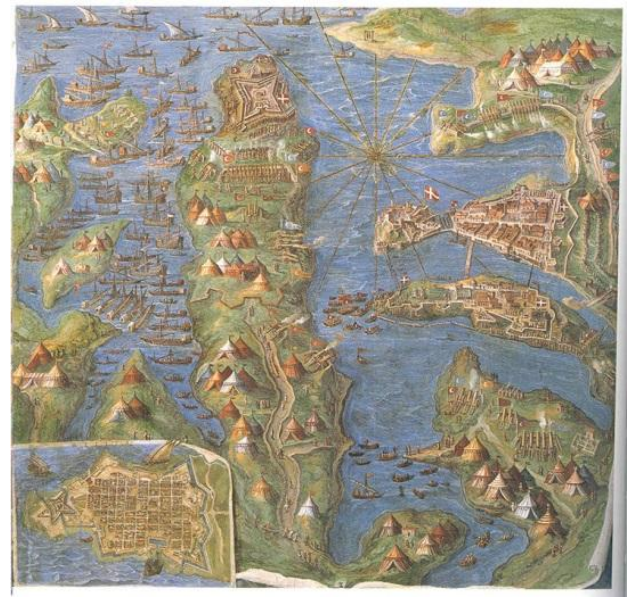

Fig. 1- Map of the Malta Siege in 1565 (Ignazio Danti, 1580-83)

Military architecture is also reflected in the bastions: the «Cottonera» is a massive line of fortifications surrounding the three cities of Vittoriosa, Cospicua and Senglea in Malta. The Grand Master Cottoner I from Olesa made its City bastions built by the Italian engineer Antonio Maurizio Valperga in the seventeenth century. Between 1635 and 1645 Pietro Paolo Floriani built Floriana, a fortification line outside Valletta, the capital of Malta,. During the second half of the seventeenth century, Malta used French and Dutch models of enrichment, not only because the treaties of these countries were well known, but also because of the presence of French engineers and Dutch residents or travellers, especially Médéric Blondel, between 1659 and 1698, and Carl Crunenberg between 1681 and 1690 .

\section{Military engineers and «Langues»}

In the second half of the seventeenth century, in 1676 Preste Sébastien Vauban, «engineer of the King» and field marshal of the army of Louis
$\mathrm{XIV}$, led the «Corps of Engineers»: this body was immediately assigned to the territory management, the border definition, and the French territory «castraméntation», very important to strengthen the new absolutist model of government. This training model was soon copied throughout Europe. Therefore, for nearly two centuries, the books of western military architecture reflect the innovations deriving from the adoption of the French model, that means an important training of Military engineers, with skills and a deep understanding of military tactics, mathematics, geometry, topography, hydraulics, military and civil buildings; and widespread use of polygonal fortification systems theorized by De Ville, Pagan - who visited Malta in 1645 - and Vauban.

In Malta an increasingly clear division of duties and activities in the sphere of military engineering begins to emerge during the early modern period. Resident engineers tended to act as intermediaries between the Order (represented by the congregation of fortification, a subcommittee of the council) and contractors who carried out the actual construction, while the visiting specialist rarely stayed longer then was necessary to secure council approval for his schemes and to mark out the trace. Their residence on the island could vary between a few days (as in the case of Vitelli in 1566) and several months (as with Floriani in 1635-1636) but almost never exceeded the latter period. Only Laparelli can be said to have undertaken the day-to-day oversight of his designs, although even he left Malta while the construction of Valletta was far from completed. The residents were therefore left to execute the master's concept by means of remembered conversations with him and deposited reports, plans and models.

In 1798, with the arrival of the troops sent by the «Directoire» and commanded by General Vaubois, the majority of Malta's fortifications was already finished and was not used to withstand an enemy no one had anticipated during the previous three centuries. This event meant the end of a unique historical period marked by the constant enhancement of the Maltese defensive systems. The destruction 
caused by the siege and the upheavals of the transfer of residence of the Order of Valletta can explain these losses, but fortunately copies of engineer reports on the defence of Malta in the Sixteenth, and over the following centuries, often were sent abroad and today that copies are especially conserved in Italy and Spain.

The largest private collection of documents is the engineer of the Pope, Francesco Laparelli, which includes a lot of material on Malta and is still in possession of his family. The Heritage of Grand Priorate of Lombardy, preserved at the Section of the Order of Malta in the State Archives of Turin, currently represents a series of significant archives we have for documentation of urban and rural topography of the Piedmont, while throughout the eighteenth century. The 690 «Cabrei and improvements» on the Italian Priories were kept at the National Library of Malta and the other, in number of
370, in the Archives of the Grand Magisterium in Rome. Again, the National Library of Paris has one of the richest collections of known manuscripts: these are papers and documents relating to Malta's history and especially of the religious order of knighthood, which had its seat for more than two centuries. They are located in four different «funds»: the «English Fund», the «French Fund», the «Spanish Fund» and «French New Acquisitions».

The fortifications are to be included in the political, diplomatic and economic situation of the Order of Saint John: as much important is the social context in which the Order itself was. Through the study of Maltese defences, relative to their counterparts overseas, a detailed examination of the career path of the military engineers employed can reveal the extent to which the works belong to a common European tradition.

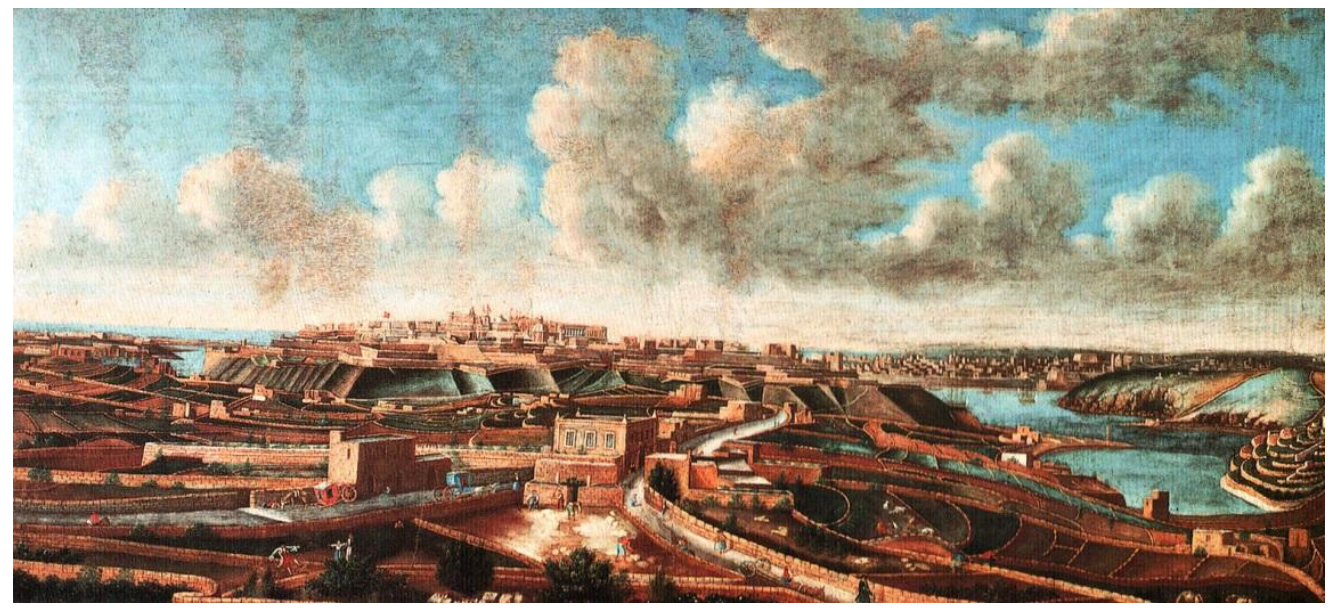

Fig. 2- View of La Valletta (Fra Giorgio Valperga di Masino, XVIIIth century)

The advantage of this material is mainly to the large amount of historical information, topographic and toponymic we can get, and also the opportunity to document the diachronic transformation and the changes in the landscape. The study of this cultural heritage, too often forgotten, is made instead of a valuable mosaic.

\subsection{Role of the Langues in the militia}

The Langues (Provence, Auvergne, France, Italy, Aragon, Castile, England and Germany) were geographical groupings of priories, which were important constituents of the organization in Malta. The Grand Master, the head of the Order, was elected by representatives of the eight Langues from among the ranks of the grand crosses. The hierarchical organization of the Order assigned, by tradition, the roles within the Langues.

The grand commander and controller of the common treasury was the pilier of Provence; the pilier of Auvergne was grand marshal and senior 
military commander; the pilier of France was grand hospitaller, and administrated the hospital; the pilier of Aragon, Catalonia and Navarre was great conservator and was responsible of the payment of subsistence allowances to knights resident in the auberges; in Italy the pilier was grand admiral and commander of the sea-borne forces; the pilier of Germany occupied the position of grand bailiff and was in overall command of fortifications beyond the harbour area; Castille and Portugal supplied the chancellor at the head of the chancery; finally, the pilier of England named the turcopilier who controlled the militia and coastguard.

By 1573 , fortifications were more or less completed, and every Language was responsible for a particular bastion or curtain: the Langue of Provence was responsible for St. John Cavalier and bastion, the Langue of Auvergne for St. Michael's Bastion and the small bastion of St. Andrew, the Langue of France for St. James Cavalier and the bastion, the Langue of Aragon, Catalonia and Navarre for the bastion of Ss. Peter and Paul, the Langue of Italy for St. Andrew's Bastion, the Langue of Germany from the entrance into the proposed ship basin all the way to St. Elmo, the Langue of Castille and Portugal for the Bastion of St. Barbara and finally the Langue of England for St. Lazarus Bastion (De Giorgio, 1985).

\subsection{Italian engineers}

In the art of fortification, Malta under knights may be considered at its best: the Italian engineers were its leading exponents in the Sixteenth Century.

In Italy, the military engineers were to develop their profession as the discipline which with the new approach to art and culture absorbed the lives of many artist/technicians to a fullness which was overflow into the adjoining countries of Europe during the Renaissance, there to flower in many different forms of development and adaptation. Military engineers started establishing themselves qualified also as respectable architects, painters, sculptors, and in some instances also as mechanical engineers, having in their time designed and created news forms of weapons. The Italian engineers, with a curious mind and a fertile imagination, although late in appreciating the advance in aggressive and defensive warfare through the introduction of new and more efficient types of fighting equipment, were nevertheless very quick in finding solutions to the structural aspects as a result of a personal participation in defensive and aggressive warfare, without which they would not have been able to appreciate the importance of every details affecting the design of fortifications. The proposals for better and improved fortifications were not only the result of drawing board exercises based on a certain amount of logic, but also on the experience gathered on the battlefield on either side of the line. Kings, Dukes and Popes looked for this type of military engineer for the execution of their projects for news fortresses and fortified centres.

It should also be noted that, from 1298 to 1798 , about 75 on 316 admirals were source of Savoy, which is a little less than a quarter (Bianchi, Gentile, 2000).

\subsection{Count Valperga}

The most significant contribution to the planning of the defences of the island of Malta was given by a technical and theoretical expert, called by the Grand Master Nicolas Cotoner: the engineer Antonio Maurizio Valperga, Baron of San Marsanotto. The great works wanted by the Grand Master Cottoner, with exceptional burden on the finances of the Order, included the great line bastion, later known Cottonera, designed by the military Valperga.

Antonio Maurizio Valperga came from a family of engineers from Turin. He served in French army led by Thomas of Savoy Carignan and Henry of Guise, which intervened in the Neapolitan revolt of 1647 . With the peace between Spain and France in 1660, he returned to Turin and in 1670 he visited Malta (Promis, 1871).

On $27^{\text {th }}$ March 1669 the Order invited Count Valperga to come to Malta for advising on the state of fortifications. He submitted his first report to the «Commissione delle Forificazioni» 
in which he referred both to the Floriana lines in order to recommend certain alterations and to the Santa Margherita fortifications. But his original suggestions on Floriana lines were not approved at first by the Council and were later superseded by a much more elaborate scheme recommending the provision of eight bastions and two demi-bastions which, with their intervening curtains, would have closed a much larger area than did Firenzuola's original scheme. Finally Grand Master Nicholas Cottoner approved the project and work was taken in hand.

In one of two letters to Carlo Emanuele II, March 28, 1670, he reports that they have started the work: «doppo li ordini di Sua Eminenza mi sono trasferto alla visita di queste fortificationi, le quali sono molto remarcabili, tagliate tutte nel rocho, ma parte tanto mal intese, che fa compassione in considerare le immense spese che si son fatte, et particolarmente la parte chiamata Floriana con muraglioni macissi di quatordeci piedi liprandi di grossessa, in altezza di vintiquatro in trenta piedi simili, et tutti li fossi et mezelune tagliati nel sasso, però esposte et situate in maniera che l'nemico la prima sera potrebbe allogiare al piede di queste».

Valperga, in his plan to correct and finish the Floriana fortifications, decided to implement his design for new works on Santa Margherita hill and also proposed supplementary outworks to correct the long acknowledge faults of the Floriana front. Before he departed in November 1670, he drew up another report on Floriana, new works on Santa Margherita hill, known as the Cottonera lines, and the new Fort Ricasoli at the entrance to Grand Harbour. Mederico Blondel, the French resident engineer - brother of the well-known mathematician and member of the Académie des Sciences François Blondel-was in Rome while Valperga was outlining the schemes and he was very critical of the Italian's ability. But despite his complaints, Blondel seems to have carried out Valperga's designs faithfully. Count Valperga was the last of the eminent Italian military engineers who were to propose and build large schemes of fortification on Malta.

\subsection{The end of Italian supremacy in fortresses}

The period between 1650 and 1750 marked the ascendency of France in European politics and as France was a nation with which the Order of Saint John had close and financial affiliations. During the course of $17^{\text {th }}$ and $18^{\text {th }}$ centuries Malta witnessed the coming and going of a number of important French military engineers: their main contribution included the establishment of a tradition of coastal fortifications, a high standard of specification of the existing harbour defences and the building of Fort Manoel, the design of which is closely related to the work of the great French military engineer Sébastien le Prestre de Vauban.

By the end of the Seventeenth Century the French had established an important corps of engineers and it was to France that the knights looked for their supply of engineers in the Eighteenth Century: the employment of men such as Tigné, Mondion and Pontleroy transferred the Order into a French sphere of influence.

\section{Conclusions}

The failure of the Order to put up a spirited resistance to Napoleon did ensure that the fortifications survived more or less intact. Although Malta was never a major European power, her fortifications are a fine example of the bastioned system of defence, popular in Europe between the Sixteenth and the Eighteenth centuries. The heavy defence burden borne by the Order of St. John, which by the late Eighteenth Century was far beyond its means, was unable in the final analysis to compensate for the growing social and moral decay, the increasing failure of nerve and doubt as to mission which such a feature of its leadership during the Napoleonic period (Hoppen, 1999). 


\section{References}

Barbero A., Merlotti A. (2009). Cavalieri. Dai templari a Napoleone. Storie di Crociati, soldati, cortigiani. Electa. Milano. pp. 121-131.

De Giorgio R. (1995). A city by an order. Progress Press. Malta. pp. 21, 129.

Demurger A. (2004). I cavalieri di Cristo. Gli Ordini religioso militari del Medioevo. XI-XVI secolo. Garzanti. Milano. pp. 115-126.

Hoppen A. (1979). The fortification of Malta by the Order of St. John 1530-1798. Scottish Academy Press. Edimburgh. pp. 22-23; 90-91.

Hugues Q. (1993). A guide to the fortifications. Said International Ltd. Valletta. pp. 105-108.

Promis C. (1871). Miscellanea di storia italiana, vol.XII. Stamperia Reale. Torino. p. 641-644.

Ricardi Di Netro T., Gentile L.C. coord. (2000). Gentilhuomini Christiani et religiosi cavalieri : nove secoli dell'Ordine di Malta in Piemonte. Electa. Milano. pp. 132-133.

Romano G., coord. (1988). Figure del Barocco in Piemonte. La corte, la città, i cantieri, le province. Cassa di Risparmio di Torino, Editris s.n.c., Torino. pp. 272-277.

Viganò M. coord. (1994). Architetti e ingegneri militari italiani all'estero dal XV al XVIII secolo. Istituto Italiano dei Castelli, Sillabe. Livorno. pp. 33-39.

Viglino Davico M., Chiodi E., Franchini C., Perin A. coord. (2008). Architetti e ingegneri militari in Piemonte tra'500 e '700. Un repertorio biografico. Omega Edizioni. Torino. pp. 17-23. 
